\title{
Determinants of and interventions for malnutrition
}

Ceylon Medical Journal 2012; 57: 51-55

Malnutrition defines both under and over nutrition. This article will cover determinants of and interventions of undernutrition.

\section{Determinants of undernutrition}

Undernutrition is a complex problem generated by factors operating at several levels and cannot be attributed only to lack of food. Therefore actions should target the different causes to achieve sustainable change. This requires a multi-sectoral approach. Figure 1 illustrates the commonly used UNICEF developed conceptual framework for understanding the causes of undernutrition [1]. Three levels of causes are identified.

1. Immediate causes which act on the individual.
2. Underlying causes that influence households and communities.

3. Basic causes which act on entire societies.

Immediate causes of undernutrition is due to an imbalance between the amount of nutrients absorbed by the body and the amount of nutrients required by the body. This happens as a consequence of consuming too little food or having an infection which either increases the bodys requirements for nutrients or prevents the body from absorbing the food consumed. Moreover, they form a vicious cycle of inadequate dietary intake which increases the likelihood of illness because of weakened immune levels, and illness leads to a loss of appetite and poor absorption which worsen undernutrition.

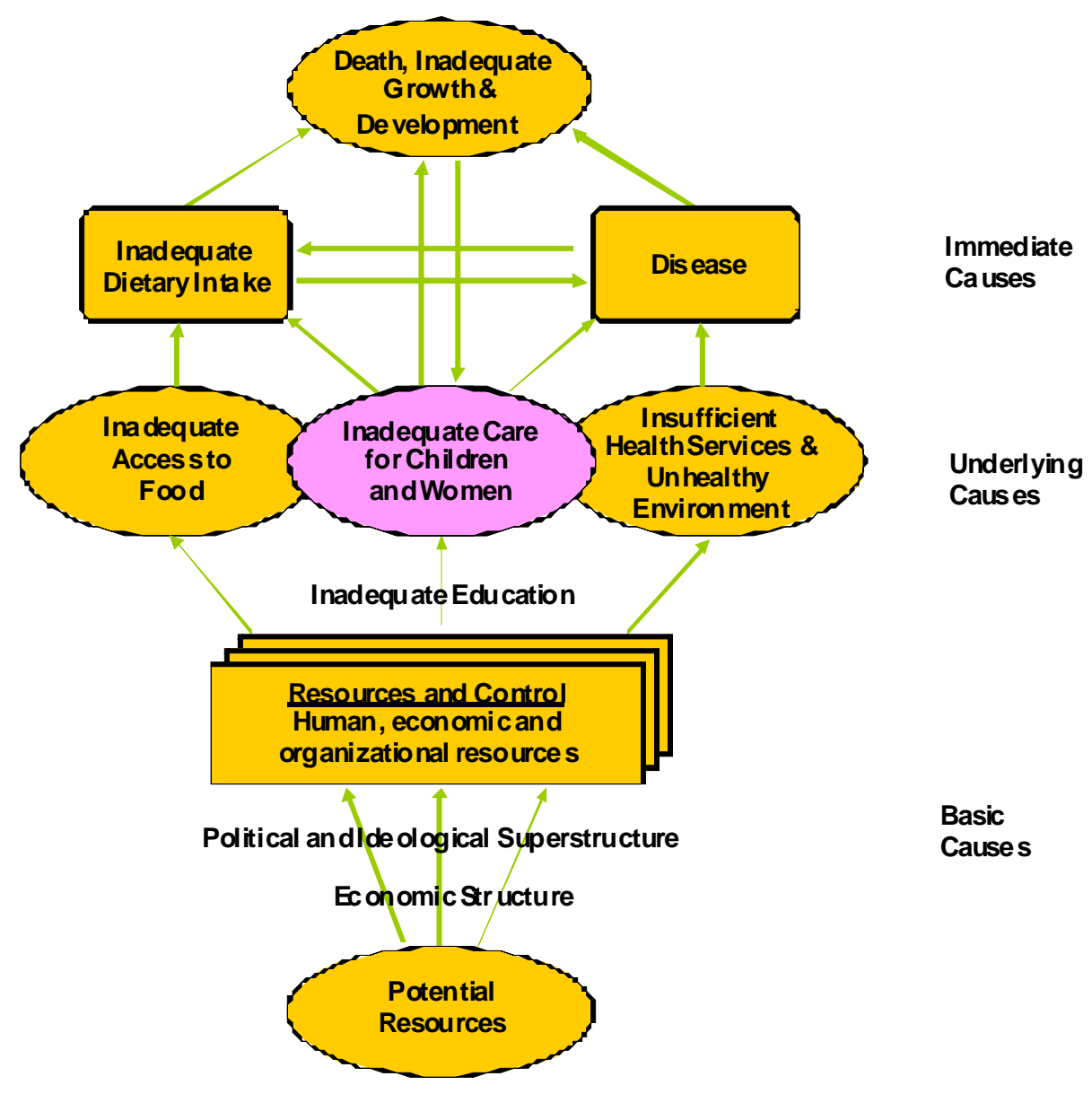

Figure 1. UNICEF conceptual framework. 
When people get infections and loose their appetite, there is an acute loss of weight, which is true for all people in all societies. However, in impoverished households there is no subsequent catch-up growth during convalescence. The diets are of insufficient quality to replace the nutrients lost during the illness and to allow them to return to normal especially with children. As an example, normal child should take $100 \mathrm{kcal} / \mathrm{kg}$ body weight/day. If the child is mildly anorexic and take only $90 \mathrm{kcal} / \mathrm{kg}$ bodyweight/day, he /she will loose $2 \mathrm{~g} / \mathrm{kg}$ body weight/day after 10 days, which is $2 \%$ of the body weight. In 3 months, the lost will be $20 \%$ of the body weight. A child weighing $10 \mathrm{~kg}$ with mild anorexia will be $8 \mathrm{~kg}$ after 3 months [2].

Underlying causes of undernutrition can be grouped under the three broad categories of food, care and health as in Figure 1. These three are interrelated, and actions affecting one area may have significant consequences on another. Each one is determined by the social and economic resources available to the individuals and the household as a whole.

Food: Household food security implies that the household has the resources to access a sufficient quantity and quality (energy, protein and micronutrients) of foods needed to ensure active and a healthy life for all members of the family. The resources needed to achieve food security are food production, income for food purchases, and /or in-kind transfers of food. It applies to foods available in a particular geographical area through local food production systems-agriculture, fisheries, livestock rearing and the food imported and exported into the country and a consideration of seasonal variations in food availability.

Care: Caring practices are the way community members, including the vulnerable such as children, the elderly and the sick, are fed, nurtured, taught and guided. It is the responsibility of the entire family and the community. The adequacy of such care practices is determined by the caregiver's control over economic resources, autonomy in decision making, physical and mental status. These are affected by the caregiver's status, relative to other members of the household.

Cultural factors and resources, like income, time, knowledge and types of health services accessible, determine the caring practices.

Health: It refers to a range of factors linked to access to health care, safe water and sanitation. An essential element of good health is access to affordable, good quality health services, and a healthy environment. Access to a safe water supply, proper sanitation systems and hygienic conditions in and around homes all influence the spread of infectious diseases. This reduces the capacity of adults to work and increases the amount of time they spend caring for sick members of the family.
Basic causes: Insufficient resources available at the country or community level, and the political, social, legal and economic conditions that govern how these resources are distributed are included under the basic causes of undernutrition in Figure 1. These include the degree to which the rights of women and girls are protected by law and custom, the political and economic system that determines how income and assets are distributed and the ideologies and policies that govern the social sectors.

\section{Types of undernutrition}

Undernutrition is defined based on anthropometric indicators, clinical signs and biochemical tests. There are four types of undernutrition [3].

i. Acute undernutrition or wasting or low weight-forheight (WFH), is caused by a decrease in food consumption and/or illness resulting in sudden weight loss. There are two main forms.

a. Severe acute undernutrition (SAM): SAM is defined by severe wasting. A child with SAM is highly vulnerable and has a high mortality risk.

b. Moderate acute undernutrition (MAM): MAM is defined by moderate wasting.

ii. Chronic undernutrition or stunting or low height-forage, is the result of prolonged episodes of undernutrition. It occurs mainly before birth and during the first two years of life.

iii. Underweight or low weight-for-age, is a composite form of undernutrition including both stunting and wasting and is defined by a weight-for-age (WFA) Z score below two standard deviations of the median of the WHO standards. This indicator is commonly used in growth monitoring and promotion and child health and nutrition programmes aimed at prevention and treatment of undernutrition.

iv. Micronutrient deficiency is a shortage of one or more vitamins or minerals. These deficiencies can negatively affect child survival and growth, women's health and pregnancy outcomes, educational achievement, adult productivity and resistance to illness.

\section{Targeted health interventions}

Table 1 gives the different types of undernutrition and the definitions by providing the targeted interventions for each type of undernutrition throughout the life cycle [2,4-8]. 
Table 1. Types of undernutrition and interventions

\section{Types of undernutrition \\ Children 0-59 months:}

Severe acute undernutrition (SAM)

Moderate acute undernutrition (MAM)

Stunting
WFH $<-3 \mathrm{Z}$ score of the median of the World Health Organization (WHO) standards.
WFH $\geq-3 \mathrm{Z}$ score and $<-2 \mathrm{z}$-score of the median of the WHO standards

\author{
Interventions
}

- Therapeutic feeding depending on whether complications are present or absent, can be done in ward or community based respectively.

- $100 \mathrm{kcal} / \mathrm{kg}$ body weight/day is needed with $100 \%$ RDA of vitamins and minerals.

- Expected weight gain is 8-10 g/day.

- Possible recovery expected within 6 weeks.

- When the child reaches the level of MAM, it is necessary to remove from the therapeutic feeding programme and to start the supplementary feeding programme given below.

- Available ready to use commercial therapeutic foods are BP-100, Plumpy' nut, F-75 and F-100.

- Supplementary feeding with correct balance of nutrients to allow appropriate amounts of lean and fat tissues.

- $90 \mathrm{kcal} / \mathrm{kg}$ body weight/day is needed with $100 \%$ RDA of vitamin and minerals adjusted for MAM children.

- Expected weight gain is $5 \mathrm{~g} / \mathrm{day}$.

- Available supplementary foods are Thriposha, Corn soya blend, Unimix.

It is best addressed through preventive maternal health programmes aimed at pregnant women, infants and children under age two.

- $\quad$ Treatment should be all years up to 5 years and prevention is important before the age of 2 years.

- Sulfur, calcium, phosphorus, magnesium, vitamin $\mathrm{D}$, vitamin $\mathrm{K}$ and copper are important micronutrients. Higher amounts are needed for the reversal of stunting.

- An increase of $1 \mathrm{~cm}$ in height should be accompanied by a weight gain about $210 \mathrm{~g}$. 


\begin{tabular}{|c|c|c|}
\hline Types of undernutrition & Definition & Interventions \\
\hline $\begin{array}{l}\text { For all children } \\
\text { between } 0-24 \text { months }\end{array}$ & $\begin{array}{l}\text { To prevent undernutrition } \\
\text { and micronutrient deficiencies }\end{array}$ & 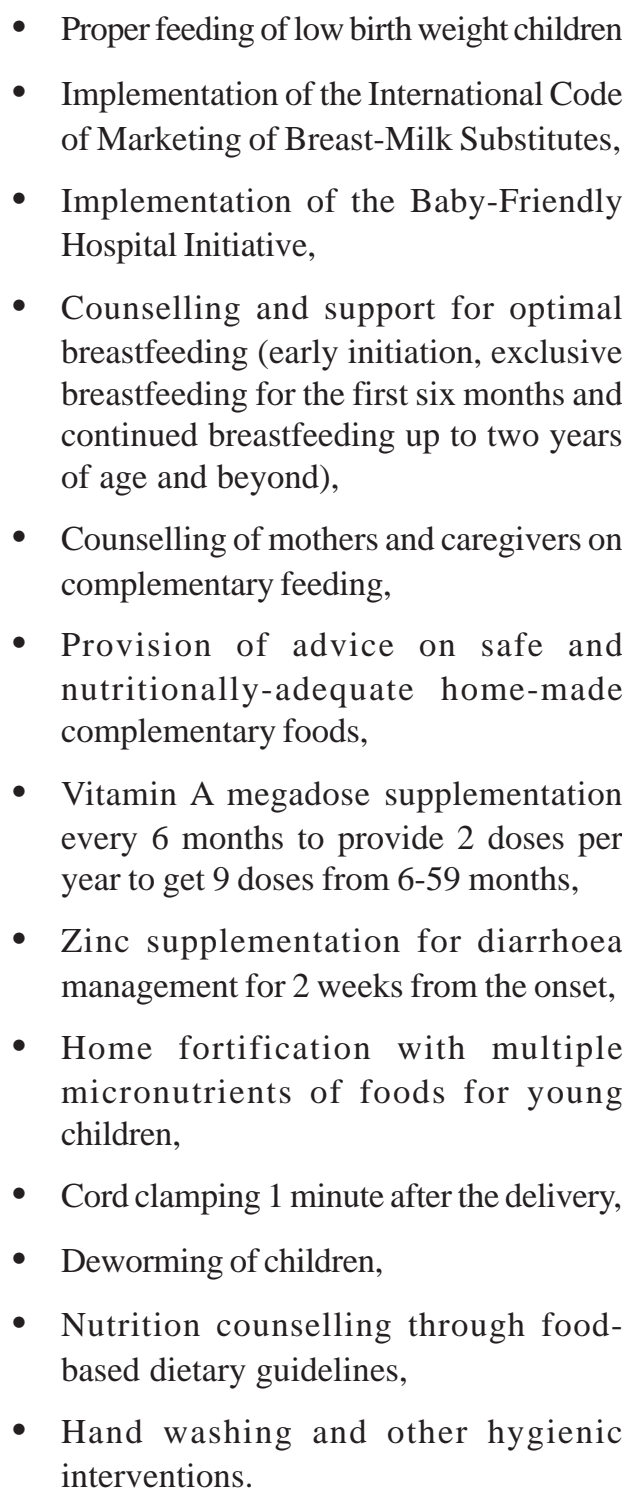 \\
\hline \multicolumn{3}{|l|}{ Adults (male and female): } \\
\hline Severe undernutrition & $<16.0 \mathrm{BMI}^{*}\left(\mathrm{~kg} / \mathrm{m}^{2}\right)$ & $\begin{array}{l}\text { - Need an extra } 1000 \mathrm{kcal} \text { of energy per day } \\
\text { with } 100 \% \text { RDA of vitamins and minerals. }\end{array}$ \\
\hline Moderate undernutrition & 16.0-16.99 BMI (kg/m²) & $\begin{array}{l}\text { - Recommended with extra } 500 \text { kcal of } \\
\text { energy with adequate quantities of } \\
\text { micronutrients. }\end{array}$ \\
\hline \multicolumn{3}{|l|}{ Pregnant women: } \\
\hline Severe undernutrition & MUAC $<19 \mathrm{~cm}$ & $\begin{array}{l}\text { - Need an extra } 700 \mathrm{kcal} \text { of energy and a } \\
\text { total of } 65 \mathrm{~g} \text { of protein per day. } \\
\text { - Iron, folic acid and calcium } \\
\text { supplementation, }\end{array}$ \\
\hline Moderate undernutrition & MUAC 19-21.9cm & $\begin{array}{l}\text { - Deworming of pregnant women and } \\
\text { breastfeeding counselling and support. }\end{array}$ \\
\hline
\end{tabular}

$(\mathrm{RDA}=$ recommended daily allowances; BMI (body mass index $)=$ weight in $\mathrm{kg} /\left(\right.$ height in meters) ${ }^{2}$

MUAC = mid upper arm circumference) 
Table 2. Non health interventions related to undernutrition

$\begin{array}{ll}\begin{array}{l}\text { Agriculture and food production } \\ \text { Social protection }\end{array} & \begin{array}{l}\text { Micronutrient fortification of staple foods and complementary foods } \\ \text { Interventions to improve food security at household level }\end{array} \\ & \begin{array}{l}\text { Conditional and unconditional cash transfers } \\ \text { Food aid }\end{array} \\ \text { Trade } & \text { Public policies to reduce food prices through reducing taxation } \\ \text { Education } & \text { Women's primary and secondary education } \\ \text { Labour } & \text { Support to lactating working women } \\ \text { Information } & \text { Conducting social marketing campaigns }\end{array}$

\section{Non health Interventions}

Due to the multi-factorial nature of undernutrition, it needs many non health interventions to sustain the interventions listed above. Table 2 provides the evidence based non health interventions identified by the WHO [7].

Undernutrition happens in the very early years, and often during pregnancy leading to low birth weight. This early damage in children's cognitive and growth potential is tragically irreversible. Interventions should be accelerated on this window of opportunity in a child's life. World Bank points out, enhanced knowledge and information will likely be sufficient to improve undernutrition among non-poor, conserving larger public resources to target the poor with more resource intensive direct nutrition interventions [10].

\section{References}

1. UNICEF. Strategy for improving nutrition of children and women in developing countries, United Nations Children's Fund, New York, USA;1990.

2. Golden MH. Proposed recommended nutrient densities for moderately malnourished children. Food and Nutrition Bulletin 2009; 30: S267-342.

3. World Health Organisation. Physical status: the use and interpretation of anthropometry - report of a WHO Expert Committee. WHO Technical Report Series 854, Geneva; 1995.

4. Black RE, Allen LH, Bhutta ZA, et al. Maternal and child undernutrition: global and regional exposures and health consequences. The Lancet Series on Maternal and Child Undernutrition 2008; 5-22.

5. World Health Organization and the United Nations Children's Fund. Community-based management of severe acute malnutrition: a joint statement by the World Food Programme, the United Nations System Standing Committee on Nutrition, Geneva; 2007.

6. Prudhon C, Briend A, Weise Prinzo Z, Daelmans BM, Mason JB. Food and Nutrition Bulletin: WHO, UNICEF, and SCN informal consultation on community-based management of severe malnutrition in children. Tokyo: International Nutrition Foundation; 2006.

7. Bhutta ZA, Ahmed T, Black RE, et al. What works? Interventions for maternal and child undernutrition and survival: maternal and child undernutrition 3. The Lancet Series on Maternal and Child Undernutrition 2008; 1-24.

8. Jones G, Steketee RW, Black RE, et al. How many child deaths can we prevent this year? Lancet 2003; 362: 65-71.

9. Shrimpton R, Victora CG, de Onis M, et al. Worldwide timing of growth faltering: revisiting implications for interventions. Pediatrics 2010; 125: e473-e480.

10. World Bank. Malnutrition in Sri Lanka: scale, scope, causes, and potential response. September 2007.

\section{R Jayatissa}

Department of Nutrition, Medical Research Institute, Colombo, Sri Lanka.

Correspondence: RJ, e-mail: <renukajayatissa@ymail.com>. 